\title{
Altered p53 in microdissected, metachronous, premalignant and malignant oral lesions from the same patients
}

University of

Cincinnati College of

Medicine,

Cincinnati,

Ohio 45267, USA:

Department of

Otolaryngology-Head

and Neck Surgery

$\mathrm{Y}-\mathrm{Q} \mathrm{Li}$

Z P Pavelic

L-J Wang

J S McDonald

L Gleich

L J Pavelic

$\mathrm{K} M$ Wilson

J L Gluckman

Department of Cell Biology,

Neurobiology and

Anatomy

P J Stambrook

Karolinska Hospital,

Stockholm,

Sweden:

Department of

Otorhinolaryngology

Head and Neck

Surgery

E Munck-Wikland

University of Zagreb, Croatia:

Department of

Pathology,

Medical School

$S$ Dacic

Z Danilovic

Correspondence to: Dr Zlatko P Pavelic, Division of Molecular Oncology,

Department of

Otolaryngology-Head and

Neck Surgery,
University of Cincinnati

University of Cincinn

231 Bethesda Avenue

\#0528,

\#0528,

Ohio 45267-0528, USA.

Accepted for publication

15 June 1995
Y-Q Li, Z P Pavelic, L-J Wang, J S McDonald, L Gleich, E Munck-Wikland, S Dacic, Z Danilovic, L J Pavelic, K M Wilson, J L Gluckman, P J Stambrook techniques, increased p53 protein has been reported in $50-60 \%$ of head and neck cancers. ${ }^{10-13}$ Stabilisation of $\mathrm{p} 53$ protein, allowing immunohistochemical detection, frequently accompanies $p 53$ mutation. ${ }^{1415}$ Mutation at $p 53$ also is commonly associated with loss of the normal allele on the short arm of chromosome 17 , where $p 53$ is located. ${ }^{16}{ }^{17}$ In colorectal cancer, mutation and loss of heterozygosity at $p 53$ is a late event in tumorigenesis. ${ }^{1819}$ In contrast, p53 mutation appears to be an early event in oesophageal cancers, ${ }^{20}$ lung cancers, ${ }^{21}$ and other types of tumour. ${ }^{223}$

To gain a better understanding of the role and timing of $p 53$ gene overexpression and mutation in head and neck cancer, biopsies of premalignant lesions and malignant tumours that developed at the same sites at a later time were analysed by immunohistochemistry and DNA sequencing from polymerase chain reaction (PCR) amplified DNA from microdissected slide preparations.

\section{Methods}

SAMPLE SELECTION

Eight paraffin embedded tumour sections, along with their premalignant counterparts (leukoplakia and dysplasia), were collected from the Karolinska Hospital, Stockholm, Sweden, and the University Hospital of Zagreb, Croatia. mours at the same site.

(f Clin Pathol: Mol Pathol 1995;48:M269-M272)

Keywords: Oral cancer, $p 53$ gene, mutations, loss of heterozygosity.

Premalignant lesions in the oral cavity and upper aerodigestive tract are at risk of progressing to invasive cancers. ${ }^{12}$ The molecular basis of facilitated progression in these tumours is not well understood. Several proto-oncogenes, including $c-m y c, N$-ras, bcl-1, and int2 , among others, have been reported to be amplified, overexpressed, or both in a large percentage of head and neck cancers. ${ }^{3-6}$ Furthermore, mutation of the $p 53$ gene occurs in many different types of human cancers, ${ }^{7-9}$ including squamous cell carcinoma of the head and neck. ${ }^{1011}$ Using immunohistochemical

\section{IMMUNOHISTOCHEMISTRY}

The premalignant and malignant pathology was confirmed by ZPP and JSM. Tissue sections $5 \mu \mathrm{m}$ thick were mounted on polylysin coated slides. A method for revealing previously inaccessible epitopes in paraffin embedded tissues was recently described by Shi et $a l^{24}$ and Pavelic et al. ${ }^{25}$ Immunostaining was done with the mouse antihuman p53 specific monoclonal antibody (PAb 1801, a gift from Oncogene Science Inc, Manhesset, New York, USA) using the PAP technique described by Pavelic et al. ${ }^{26}$ The intensity scores $(0$, none; + , weak; ++ intermediate; +++ , strong) were evaluated by two independent pathologists in a blinded fashion (ZPP, JSM). 
Immunohistochemical detection of p53 and mutation at p53 in metachronous premalignant and cancerous lesions

\begin{tabular}{|c|c|c|c|c|c|c|c|c|c|c|}
\hline \multirow[b]{2}{*}{ Patient } & \multirow[b]{2}{*}{$\begin{array}{l}\text { Age } \\
\text { (years)/sex }\end{array}$} & \multicolumn{3}{|c|}{ Premalignant lesions } & \multirow[b]{2}{*}{ Mutation } & \multicolumn{2}{|l|}{ Cancer } & \multicolumn{2}{|c|}{ Mutation } & \multirow[b]{2}{*}{$\begin{array}{l}\text { Sequence } \\
\text { change }\end{array}$} \\
\hline & & Type & $\begin{array}{l}\text { Year of } \\
\text { appearance }\end{array}$ & $\begin{array}{l}\text { p53 } \\
\text { staining }\end{array}$ & & $\begin{array}{l}\text { Year of } \\
\text { appearance }\end{array}$ & $\begin{array}{l}\text { p53 } \\
\text { status }\end{array}$ & exon & codon & \\
\hline 1 & $72 / \mathrm{M}$ & $\mathrm{L}$ & 1985 & + & - & 1993 & ++ & - & & \\
\hline 2 & $49 / M$ & $\overrightarrow{\mathrm{L}}$ & 1983 & - & - & 1988 & + & - & & \\
\hline 3 & $71 / \mathrm{M}$ & $\mathrm{L}$ & 1988 & + & - & 1990 & +++ & $\begin{array}{l}8 \\
5\end{array}$ & $\begin{array}{l}273 \\
164\end{array}$ & $\begin{array}{l}\text { CGT } \rightarrow \text { CAT } \\
\text { AAG } \rightarrow \text { AAT }\end{array}$ \\
\hline 4 & $64 / F$ & $\mathrm{~L}$ & 1984 & - & - & 1991 & - & - & & \\
\hline 5 & $60 / \mathrm{M}$ & $\mathrm{L}$ & 1991 & - & - & 1992 & - & - & & \\
\hline 6 & $58 / \mathrm{M}$ & $\mathrm{L}$ & 1978 & - & - & 1987 & + & - & & \\
\hline 7 & $79 / \mathrm{M}$ & $\mathrm{D}$ & 1986 & + & - & 1987 & $++t$ & 5 & 143 & $\mathrm{GTG} \rightarrow \mathrm{TTG}$ \\
\hline 8 & $73 / \mathrm{M}$ & $\mathrm{L}$ & $6 / 1987$ & - & - & $11 / 1987$ & - & - & & \\
\hline
\end{tabular}

$\mathrm{L}=$ leukoplakia $; \mathrm{D}=$ dysplasia

\section{DNA ISOLATION}

Genomic DNA was prepared directly from microdissected tissue. In the specimens that had moderate to intense p53 staining, tissue was selected from reactive regions. The tissue samples were dewaxed by two washes in xylene and one wash in $95 \%$ ethanol, then digested with proteinase $\mathrm{K}(0.2 \mathrm{mg} / \mathrm{ml})$ in a buffer containing $50 \mathrm{mM}$ Tris, $1 \mathrm{mM}$ EDTA, and $0.5 \%$ Tween 20 at $37^{\circ} \mathrm{C}$ for $3 \mathrm{~h}$ or overnight.

\section{PCR AMPLIFICATION}

PCR primers were synthesised based on the published sequences. ${ }^{26}$ The reaction was performed in a volume of $50 \mu \mathrm{l}$ in $10 \mathrm{mM}$ Tris$\mathrm{HCl}, 50 \mathrm{mM} \mathrm{KCl}, 1.5 \mathrm{mM} \mathrm{MgCl}, 0.01 \%$ (wt/vol) gelatin, and 2.5 units of Taq DNA polymerase, with the deoxynucleotide triphosphates (dNTP) at a final concentration of $200 \mu \mathrm{M}$ each, primers at $10 \mathrm{pmol}$, and template DNA for 50 cycles under the following condition: $20 \mathrm{~s}$ at $94^{\circ} \mathrm{C}$ (denature); $30 \mathrm{~s}$ at $55^{\circ} \mathrm{C}$ (annealing); $30 \mathrm{~s}$ at $72^{\circ} \mathrm{C}$ (extension) and with final step extension at $72^{\circ} \mathrm{C}$ for $7 \mathrm{~min}$. PCR products were fractionated by $1.5 \%$ Seaplaque agarose gel. The corresponding DNA bands were excised and purified with Gene Clean Kit (Bio 101). Purified DNA samples were subjected to thermal cycles of DNA sequencing.

\section{SEQUENCING OF PCR PRODUCTS}

The sequencing primer was one of a pair of PCR primers used for exon amplification. ${ }^{27}$ Sequencing was done in accordance with the manufacturer's protocol $\left(\right.$ Vent $\mathrm{T}^{\mathrm{M}}$ thermal cycles dideoxy DNA sequencing kit, New England Biolab $)^{28}$ for 20 cycles under the following conditions: $94^{\circ} \mathrm{C}$ for $20 \mathrm{~s}, 55^{\circ} \mathrm{C}$ for $20 \mathrm{~s}$, and $72^{\circ} \mathrm{C}$ for $20 \mathrm{~s}$. The sequencing products were resolved by $7 \mathrm{M}$ urea-6\% PAGE.

\section{LOSS OF HETEROZYGOSITY}

The DNA from premalignant and malignant lesions was evaluated for loss of heterozygosity. A highly polymorphic dinucleotide repeat polymorphism marker at the human $p 53$ locus was used to detect loss of heterozygosity. ${ }^{29}$ Primers were synthesised flanking a (CA) ${ }_{25}$ repeat to give a 116 bp product: GT strand primer: AGGGATACTATTCAGCCCGAGGTG; AC strand primer: ACTGCCACTCCTTGCC-
CCATTC. PCR was performed at an initial temperature of $94^{\circ} \mathrm{C}$ for $3 \mathrm{~min}$ for 35 cycles under the following conditions: $30 \mathrm{~s}$ at $94^{\circ} \mathrm{C}$, $1 \mathrm{~min}$ at $62^{\circ} \mathrm{C}$, and a final extension for $5 \mathrm{~min}$ at $72^{\circ} \mathrm{C}$. Reaction products were resolved with a $10 \%$ polyacrylamide gel, stained with ethidium bromide, and photographed. The results were analysed to determine changes in allele intensity between normal and tumour tissue.

\section{Results}

Immunohistochemical staining with anti-p 53 monoclonal antibody produced positive staining in three of eight of premalignant lesions and five of eight of malignant lesions. Three of the five patients whose oral cancer was p53positive by immunohistochemistry also had immunohistochemically detectable p53 in their previous premalignant lesions. These lesions had been removed 1 year (patient 7), 2 years (patient 3 ), and 8 years (patient 1), respectively, before a tumour developed. These data, summarised in the table, show that stabilisation of p53 protein can occur in the very early stage of oral cavity tumorigenesis. Adjacent normal tissue did not stain with the anti-p 53 antibody.

To determine whether or not the increased cellular level of p 53 protein was due in each case to mutation in $p 53$, we performed direct genomic sequencing of PCR amplified product of exons $5,6,7$, and 8 , which include the majority of known mutated sites. None of the premalignant lesions showed $p 53$ mutations within this region (table). Two of the eight cancer patients (patient 3 and patient 7) had two missense mutations in $p 53$ (table). One patient (P3) had two missense mutations, one at the second base of codon 273 (CGT to CAT) causing an amino acid change from arginine to histidine, and the other at codon 164 (AAG to AAT) causing a lysine to asparagine change (figure). The other (P7) had mutation at codon 143 (GTG to TTG) causing an amino acid change from valine to leucine (figure).

In all three cases, the sequencing gels displayed a wild type band in the same position as the mutant band (figure), indicative of two alleles. That there was no loss of heterozygosity was confirmed by microsatellite analysis (data not shown). The other three malignant tumours and the three premalignant lesions which stained positive with antibody to p 53 did not reveal mutations within the regions sequenced. 
A

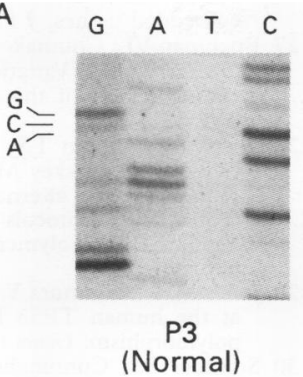

B

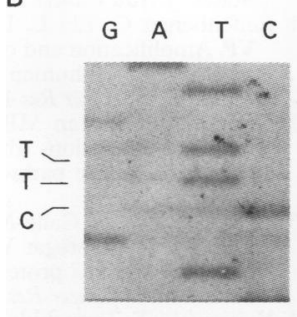

P3

(Normal)

G A $\quad T \quad C$

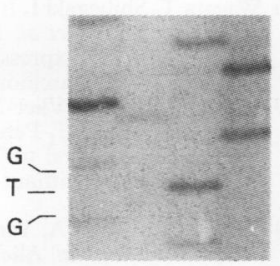

P7

(Normal)

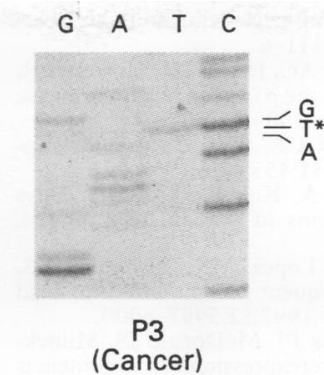

$\begin{array}{llll}\text { G } & \mathrm{A} & \mathrm{T} & \mathrm{C}\end{array}$

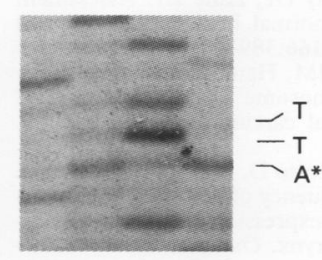

P3

(Cancer)

G A $\quad \mathrm{T} \quad \mathrm{C}$

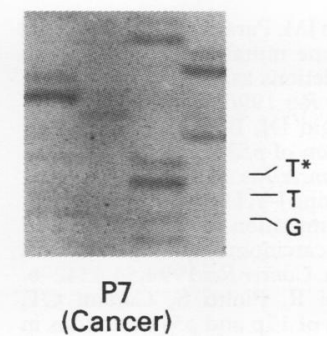

Representative sequence analysis of $p 53$ in samples from patients 3 and 7. Each exon and its splice junctions were sequenced in both directions as detailed in Methods. Panels $A$ and $B$ depict sequence extended from an antisense primer, and panel $C$ from a sense primer. All three gels show a wild-type band of equal intensity to the mutant band, suggesting that the tumours are heterozygous for mutant and normal p53 at those codons.

\section{Discussion}

The important finding in this study was that three of five patients whose cancer tissue had immunodetectable p53 also manifested p53 staining in the premalignant lesion at the same site 1-8 years before a tumour developed. These results suggest that immunohistochemical detection of p53 can occur very early in head and neck tumorigenesis. The number of patients presented here is necessarily small because of the scarcity of cohorts in which metachronous lesions are available for study. This report is the first to describe p53 staining in head and neck cancer and in a corresponding earlier premalignant sample from the same patient.

It is possible that mutations may have occurred outside the region sequenced (that is, exons 5-8). However, other studies in which the complete $\mathrm{cDNA}$ mutations were screened found very few mutations outside this region. ${ }^{30}$ Alternatively, staining could be facilitated by activating expression of other genes encoding proteins that might interact with or stabilise p53, such as that which encodes the murine double minute 2 (MDM2) gene product. ${ }^{31}$ Staining of cells in the preneoplastic lesions could also be a result of exposure to xenobiotics and localised DNA damage, which in turn can induce a rise in $\mathrm{p} 53 .^{32}$

To determine whether or not p53 immunostaining or $p 53$ mutation are related to loss of heterozygosity, we used a highly polymorphic marker to detect loss of heterozygosity at $p 53$. No evidence of loss of heterozygosity was found in either the premalignant or the malignant lesions, including two specimens with mutations. This was in contrast to other reports of frequent loss of heterozygosity seen in colorectal carcinoma, ${ }^{33}$ osteosarcoma, ${ }^{34}$ and other cancers. ${ }^{35}$ The observation of mutation at $p 53$ with maintenance of heterozygosity seen in our patients has also been observed by others. ${ }^{36}$ It is possible that loss of heterozygosity occurred distal to the region screened since a second locus, distal to $p 53$, at $17 \mathrm{p} 13.3$ appears to be involved in loss of heterozygosity in breast cancers, ${ }^{3738}$ astrocytomas, ${ }^{39}$ neuroectodermal tumours, ${ }^{40}$ and hepatocellular carcinoma. ${ }^{41}$ In preliminary studies by us (unpublished data) using a highly polymorphic probe (p144D6 and P68RS2.0) with Southern blotting, loss of heterozygosity was found at loci on chromosome 17 p13.3 and $13 q 14$, leaving the $p 53$ gene itself unaffected.

Our findings that p53 status differs in premalignant and malignant tissues are in contrast to earlier reports in which the same $p 53$ mutation was found in premalignant and malignant tissue from the same patient. ${ }^{4243}$ However, it is important to recognise that the experimental paradigm was not the same. In the earlier reports, the premalignant specimen was obtained from tissue in proximity to the tumour, and may have arisen from the same progenitor cell that gave rise to the tumour proper. In the present report, the premalignant and malignant samples were obtained from the same site but at different times. Even though in two cases both premalignant and counterpart malignant lesions stained with antibody to p53, only the malignant specimen had a mutation in p53 within the region assayed.

These results show that p53 protein accumulation, but not gene mutation, may occur at a very early stage of oral cavity tumorigenesis, suggesting that the accumulation of $\mathrm{p} 53$ protein was mutated by a $p 53$ mutation independent mechanism.

The authors wish to thank Ms Nancy J Nichols and Ms Janice Tedesco for their secretarial assistance in preparing this manuscript. This work was supported in part by the Swedish Cancer Society. KMW was a recipient of the American Cancer Society Society. KMW was a recipient of the American
Clinical Oncology Career Development Award

1 Shklar G. Oral leukoplakia. N Engl f Med 1986;315:1544-6. Mashberg A. Erythroplasia vs leukoplakia in the diagnosis of early asymptomatic oral squamous carcinoma. $N$ Engl f Med 1977;297:109-10.

3 Yokota J, Tsunetsugu-Yokota Y, Battifora $\mathrm{H}$, Le-Fevre C, Cline MJ. Alterations of myc, myb, and ras $^{\mathrm{Ha}}$ protoongenes in cancers are frequent and show clinical correlation. Science 1986;231:261-5.

4 Spandidos DA, Lamothe A, Field JK. Multiple transcriptional activiation of cellular oncogenes in the human head and $221-4$.

5 Somers KD, Cartwright SL, Schechter GL. Amplification of the int-2 gene in human head and neck squamous cell carcinomas. Oncogene 1990;5:915-20. 
6 Berenson JR, Yang J, Mickel RA. Frequent amplification of the bcl-1 locus in head and neck squamous cell carcinomas. Oncogene 1989;4:1111-6.

7 Nigro JM, Baker SJ, Presinger AC, Jessup JM, Hostetter R, Cleary $\mathrm{K}$, et al. Mutations in the $p 53$ gene occur in diverse human tumour types. Nature 1989;342:705-8.

8 Levine AJ, Momand J, Finlay CA. The $p 53$ tumour suppressor gene. Nature 1991;351:453-456.

9 Miller CW, Simon K, Aslo A, Kok K, Yokota J, Buys CHCM, et al. P53 Mutations in human lung tumors. Cancer Res 1992;52:1695-8.

10 Somers KD, Merrick MA, Lopez ME, Incognito LS, Schechter GL, Casey G. Frequent P53 mutations in head and neck cancer. Cancer Res 1992;52:5997-6000.

11 Pavelic ZP, Li Y-Q, Stambrook PJ, McDonald JS, MunckWikland E, Dacic S, et al. Overexpression of $\mathrm{p} 53$ protein is Wikland E, Dacic $S$, et al. Overexpression of p53 protein is common in premaligna $1994 ; 14: 2259-66$.

12 Watling DL, Gown AM, Coltrera MD. Overexpression of P53 in head and neck cancer. Head Neck 1992;14:437-44.

13 Ogden GR, Kiddie RA, Lunny DP, Lane DP. Assessment of p 53 protein expression in normal, benign and malignant oral mucosa. F Pathol 1992;166:389-94.

14 Baker SJ, Fearon ER, Nigro JM, Hamilton SR, Preisinger $\mathrm{AC}$, Jessup JM, et al. Chromosome 17 deletions and p53 gene mutations in colorectal carcinomas. Science 1989; 224:217-21.

15 Maestro R, Dolcetti R, Gasparotto D, Doglioni C, Pelucchi $\mathrm{S}$, Barzan L, et al. High frequency of $p 53$ gene alterations associated with protein overexpression in human squamous cell carcinoma of the larynx. Oncogene 1992;7:115966.

16 Iggo R, Gatter K, Barrtek J, Lane D, Harris AL. Increased expression of mutant forms of $p 53$ oncogene in primary lung cancer. Lancet 1990;335:675-9.

17 Sameshima J, Matsuno Y, Hirohashi S, Shimosat Y, Mizoguchi $\mathrm{H}$, Sugimura $\mathrm{T}$, et al. Alteration of the $p 53$ gene are common and critical events for the maintenance of are common and critical events for the maintenance of malignant phenotyp

18 Baker SJ, Preisinger AC, Jessup JM, Paraskeva C, Markowitz $\mathrm{S}$, Wilson JKV, et al. p53 gene mutations occur in combination with $17 \mathrm{p}$ allelic deletions as late events in colorectal tumorigenesis. Cancer Res 1990;50:7717-22.

19 Cunningham J, Lust JA, Schaid DJ, Bren GD, Carpenter HA, Rizza E, et al. Expression of $p 53$ and $17 p$ allelic loss in colorectal carcinomas. Cancer Res 1992;52:1974-80.

20 Gao H, Wang L-D, Zhou Q, Hong J-Y, Huang T-Y, Yang CS. $p 53$ tumor suppressor gene mutation in early esophageal precancerous lesions and carcinoma among high-risk precancerous

21 Sozzi G, Miozzo M, Donghi R, Pioltti S, Cariani CT, Pastorino $U$, et al. Deletions of $17 p$ and $p 53$ mutations in Pastorino $U$, et al. Deletions of $17 p$ and $p 53$ mutations in
preneoplastic lesions of the lung. Cancer Res 1992;52: preneoplastic

22 Bennett WP, Colby TV, Tranis WD, Barkowski A, Jones RT, Lane DP, et al. p53 protein accumulates frequently in early bronchial neoplasia. Cancer Res 1993;53:4817-22.

23 Dolcetti R, Doglioni C, Maestro R, Gasparotto D, Bazan $\mathrm{L}$, Pastore A, et al. $p 53$ overexpression is an early event in the development of human squamous cell carcinoma of the larynx: genetic and prognostic implications. Int $\mathcal{F}$ Cancer 1992;52:178-82.

24 Shi SR, Key ME, Kalra KL. Antigen retrieval in formalinfixed, paraffin-embedded tissues. 7 Histochem Cytochem 1991;39:741-8.

25 Pavelic ZP, Portugal LG, Gootee MJ, Stambrook PJ, Smith C, Mugge RE, et al. Retrieval of $p 53$ protein in paraffinembedded head and neck tumor tissues. Arch Otolaryngol Head Neck Surg 1993;119:1206-9.

26 Pavelic K, Pavelic ZP, Denton D, et al. Immuno- histochemical detection of c-myc oncoprotein in paraffin embedded tissues. $\mathcal{F}$ Exp Pathol 1990;5:143-53.

27 Buchman VL Chumakov PM, Ninkina NN, Samarina OP Georgiev GPA. Variation in the structure of the proteincoding region of the human P53 gene. Gene 1988;70: 245-52.

28 Sears LE, Moran LS, Kissinger C, Creasey T, PerryO'Keefe $\mathrm{H}$, Roskey $M$, et al. CircumVent thermal cycle sequencing and alternative manual and automated DNA sequencing protocols using the highly thermostable Vent $_{\mathrm{R}}{ }^{\mathrm{TM}}$ DNA polymerase. $\mathcal{f}$ Lab Technol Biores 1992;13. 626-33.

29 Jones MH, Nakamura Y. Detection of loss of heterozygosity at the human TP53 locus using a dinucleotide repeat polymorphism. Genes Chromosomes Cancer 1992;5:89-90.

30 Sommer SS, Cunningham J, McGovern RM, Saitoh S Schroeder JJ, Wold LE, et al. Pattern of $p 53$ gene mutations Schroeder JJ, Wold LE, et al. Pattern of $p 53$ gene mutations in breast cancers of women of the midwest
States. $\mathcal{F}$ Natl Cancer Inst 1992;84:246-52.

31 Reifenberger G, Liu L, Ichimura K, Schmidt EE, Collin VP. Amplification and overexpression of the MDM2 gen in a subset of human malignant gliomas without $p 53$ mutations. Cancer Res 1993;53:2736-9.

32 Nelson WG, Kastan MB. DNA strand breaks: the DNA template alterations that trigger $p 53$-dependent DNA damage response pathways. Mol Cell Biol 1994:14:181523.

33 Campo E, de la Calle-Martin O, Miquel R, Palacin A, Romero M, Fabregat V, et al. Loss of heterozygosity of $p 53$ gene and $p 53$ protein expression in human colorectal carcinomas. Cancer Res 1992;51:4436-42.

34 Yamaguchi T, Toguchida J, Yamamuro T, Kotoura Y, Takada N, Kawaguchi N, et al. Allelotype analysis in osteosarcomas: frequent allele loss on $3 \mathrm{q}, 13 \mathrm{q}, 17 \mathrm{p}$, and $13 \mathrm{q}$ Cancer Res 1992;52:2419-23.

35 Largey JS, Meltzer SJ, Yin J, Norris K, Sauk JJ, Archibald DW. Loss of heterozygosity of $p 53$ in oral cancers demonstrated by the polymerase chain reaction. Cancer 1993; 71:1933-7.

36 Wagata T, Shibagaki I, Imamura M, Shimada Y, Toguchida $\mathrm{J}$, Yandell DW, et al. Loss of $17 \mathrm{p}$, mutation of the $p 53$ gene, and overexpression of $p 53$ protein in esophagea squamous cell carcinomas. Cancer Res 1993:53:846-50.

37 Cornelis RS, van Vliet M, Vos CBJ, Cleton-Jansen A-M, van de Vijver MJ, Peterse JL, et al. Evidence for a gen on $17 \mathrm{p} 13.3$, distal to TP53, as a target for allele loss in breast tumors without $p 53$ mutations. Cancer Res 1994; $54: 4200-6$.

38 Sato T, Tanigami A, Yamakawa K, Akiyama F, Kasumi F, Sakamoto G, et al. Allelotype of breast cancer: cumulative allele losses promote tumor progression in primary breast cancer. Cancer Res 1990;50:7184-9.

39 Saxena A, Clark WC, Robertson JT, Ikejiri B, Oldfield EH, Ali IU. Evidence for the involvement of a potential second tumor suppressor gene on chromosome 17 distinct from p53 in malignant astrocytomas. Cancer Res 1992;52:671621.

40 Biegel JA, Burk CD, Barr FG, Emanuel BS. Evidence for a $17 \mathrm{p}$ tumor related locus distinct from $p 53$ in pediatric primitive neuroectodermal tumors. Cancer Res 1992;52: 3391-5.

41 Nishida N, Fukuda Y, Kokuryu H, Toguchida J, Yandell DW, Ikenega $\mathrm{M}$, et al. Role and mutational heterogeneity of the $p 53$ gene in hepatocellular carcinoma. Cancer Res of the p53 gene

42 Shin DM, Kim J, Ro JY, Hittelman J, Roth JA, Hong WK, et al. Activation of $p 53$ gene expression in premalignant lesions during head and neck. Cancer Res 1994;54:321-6.

43 Voravud N, Shin DM, Ro JY, et al. Increased polysomies of chromosomes 7 and 17 during head and neck multistage tumorigenesis. Cancer Res 1993;53:2874-83. 